\title{
Jogos, poemas, fantasias: a posição da criação em Freud*
}

\author{
Games, poems, fantasies: the position of creation in Freud
}

\author{
Pedro Fernandez de Souza \\ pedrofsouza@gmail.com \\ (Universidade Federal de São Carlos, São Paulo, Brasil)
}

\begin{abstract}
Resumo: Este artigo tenta compreender o papel da poesia em Freud a partir da relação que ela entretém com o processo criativo de um modo geral. Se Freud acaba por aproximar, genética e formalmente, a criação literária dos jogos infantis e das fantasias adultas, a poesia e sua eficácia são quase que reduzidas a uma técnica - que ele, por fim, não consegue capturar com seus conceitos. Assim, numa leitura pormenorizada, não são as semelhanças entre as três classes de produção psíquica que se sobressaem, mas sim essa diferença última e enigmática, importante resíduo proveniente da reflexão freudiana mesma.
\end{abstract}

Palavras chaves: Freud; psicanálise; Keywords: Freud; psychoanalysis; literature; literatura; criação; fantasia.

\begin{abstract}
This article aims to understand the role of poetry in Freud based upon the relation it has with the creative process in general. If Freud ends up approximating, genetically and formally, the literary creation to the infantile games and the adult fantasies, poetry and its effectiveness are almost reduced to a technique - which he, in the end, cannot capture with his concepts. Thus, in a detailed reading, it is not the similarities between the three psychic productions that stand out, but this ultimate and enigmatic difference, an important residue ensuing from the Freudian reflection itself.
\end{abstract}

creation; fantasy.

A relação entre Freud e literatura é mais que conhecida: desde as análises de contos, peças de teatro e poemas até as citações de versos do Fausto, a frequência com que a palavra literária se incrusta na palavra freudiana é altíssima. Se na Traumdeutung Freud se utiliza da tragédia de Sófocles e do Hamlet de Shakespeare, não é simplesmente a fim de analisar tais obras, destrinchando-as como faz com os sonhos de seus pacientes e com os seus próprios; Freud parece ter, nos escritores, companheiros de um tipo muito especial em sua tentativa de investigação do inconsciente. É célebre sua afirmação de que um poeta já chegara com suas obras

* Este artigo só foi possível em virtude do financiamento da Fundação de Amparo à Pesquisa do Estado de São Paulo (FAPESP) (processo n 2019/08501-5). Agradeço também às orientações sempre benfazejas de Janaina Namba, sem cujos comentários este artigo não viria à luz. 
ao lugar a que ele chegou muito tempo depois, a partir de seu método investigativo. Como afirmou Gómez Mango (2012, p. 18), "Freud teve a coragem de introduzir no espaço do saber científico a figura do Dichter, do poeta, severamente apartado pela academia de sua época"; mas não só isso, ele também "fez do poeta um dos interlocutores primordiais de sua obra. Reconhecia na Dichtung um acesso privilegiado à verdade psíquica”. No mesmo sentido, pode-se recordar com Pagès que, na obra de Freud, há "esses momentos em que a poesia, longe de ser objeto analisado, torna-se o referencial no qual vem apoiar-se a reflexão freudiana" (Pagès, 2010, p. 16).

Percebe-se, porém, que, embora Freud conceda à poesia e ao poeta um lugar especial dentro de sua teorização, muitas vezes em seus textos os termos relativos à criação poética se encontram destituídos de qualquer excepcionalidade. É o que vemos em seu artigo publicado em 1909 sobre os romances familiares:

São particularmente as crianças mais jovens que buscam tirar de seus antecessores a prerrogativa mediante essas invenções [Dichtungen] (exatamente como nas intrigas históricas), que inclusive não se pejam de atribuir [andichten] à mãe tantos casos amorosos quantos são seus próprios concorrentes. Uma variante interessante desse romance familiar ocorre quando o herói fantasiador [dichtend] reclama para si a legitimidade, enquanto afasta como ilegítimos seus irmãos e irmãs (Freud, 2015/1909a, p. 423).

Para tratar das fantasias neuróticas, Freud usa o verbo dichten (e o seu derivado andichten) e o substantivo Dichtung, a que já fizemos alusão. E essa não é a única vez em que Freud aproxima o léxico literário do tema das fantasias. Já no artigo sobre as memórias encobridoras, em 1899, Freud dissera, a respeito da fabricação de uma memória desse tipo: "posso assegurar-lhe que muito amiúde se criam inconscientemente tais coisas, como uma criação literária [dichten], por assim dizer" (Freud, 1989/1899, p. 309). O artigo sobre as fantasias histéricas, por exemplo, se abre com a seguinte frase: "já são conhecidas as delirantes criações [Wahndichtungen] dos paranoicos, que têm por conteúdo a grandeza e os sofrimentos do seu próprio Eu e que aparecem em formas típicas, quase monótonas” (Freud, 2015/1908a, p. 340). Ao analisar as fantasias do pequeno Hans, Freud diz: "duas fantasias menores são produzidas por Hans logo após a fantasia [Dichtung] das girafas" (Freud, 2015/1909b, p. 256). No texto sobre o Homem dos Lobos, ao se analisar como em fantasias sádicas a passividade do paciente se transfigurara em atividade, lê-se: "era também adequado envolver nessa ficção [Dichtung] a governanta..." (Freud, 2010/1918 [1914], pp. 29-30). No caso do Homem dos Ratos, dissertando sobre uma importante memória encobridora do paciente, Freud alega, em nota de rodapé, que "raramente

1 A edição utilizada das obras completas de Freud foi a da Companhia das Letras. Somente em dois casos empregamos outras edições: no caso do artigo sobre as memórias encobridoras, de 1899, cuja tradução brasileira ainda não foi lançada pela Companhia das Letras, usamo-nos da edição argentina (Amorrortu Editores, 1989); e ao nos dirigirmos à versão original do artigo de 1908 sobre o escritor literário, utilizamos a edição alemã das obras completas (Gesammelte Werke, 1972). 
nos achamos na feliz situação de poder confirmar, através do inabalável testemunho de um adulto, os fatos sobre os quais se baseiam as histórias [Dichtungen] relativas ao passado remoto, como sucede no caso deste paciente" (Freud, 2013/1909c, p. 69 , nota de rodapé). Nesse mesmo texto, ao tratar das espúrias conexões operadas pela fantasia do enfermo (a equação ratos = dinheiro, filhos, fezes, pênis, bichos asquerosos..., a partir das relações gráficas e fonéticas entre os termos alemães Ratten, Raten, Spielratte, heiraten), ele chega a invocar as veleidades dos artistas como sinal de comprovação: "se o leitor sacudir a cabeça, questionando esses saltos da fantasia neurótica, tenha em mente caprichos semelhantes, a que a fantasia dos artistas eventualmente se entrega" (idem, p. 76, nota de rodapé). A temática da criação literária aparece, pois, em Freud, intimamente vinculada à da fantasia.

Assim, se por um lado os poetas têm um lugar todo especial dentro da obra freudiana, como possuintes de um acesso privilegiado à assim chamada "verdade psíquica”, e Freud chega a dizer que eles possuem "coragem para fazer seu próprio inconsciente falar" (Freud, 2013/1910a, p. 335), por outro o termo alemão específico que designa as suas criações, a Dichtung, aparece em diversos momentos da letra freudiana vinculado não a um objeto estético ou a uma criação literária, mas sim às fantasias mais banais de crianças, doentes nervosos e das pessoas ditas normais. Assim, o que se constata é que a relação entre Freud e literatura não é nada simples e, como já o disse Bayard (e a partir de uma abordagem diferente, o que é ainda mais eloquente), o conjunto de elogios que Freud endereça aos poetas, numa espécie de confissão de uma dívida para com eles, "não vai sem uma certa ambiguidade" (Bayard, 2004, p. 23).

A Dichtung e a Phantasie aparecem, pois, como atividades muito afins para a letra freudiana. Mas em que consiste essa ligação entre o poético e o fantasístico? Uma primeira resposta poderia estar no caráter de composição que é comum a ambos os domínios. O Pons Grosswörterbuch für Experten und Universität indica que Dichter é o poeta e que Dichtung é ou poesia ou poema. Segundo Gómez Mango (2012), porém, a tradução desses termos não é tão simples:

os termos alemães Dichtung e Dichter não possuem equivalentes na língua francesa nem em outras línguas europeias. As expressões "criações literárias" e "atividade poética ou do imaginário", para a primeira, e "criador literário" e "criador de ficções", para a segunda, são frequentemente utilizados na tentativa de acercar-se o máximo possível de seu significado (Mango, 2012, p. 13).

Quantas palavras para traduzir um único vocábulo alemão, que em seu caráter sintético diz mais com menos. Gómez Mango continua: “o termo Dichter, de uso corriqueiro na língua alemã, designa, em um sentido amplo, o escritor, o autor, o narrador, o dramaturgo, o criador de obras literárias; ou, num sentido mais específico, o poeta, o fazedor de poemas" (idem, ibidem). Proliferam os termos latinos, e a palavra 
alemã, majestática, permanece una. A questão torna-se ainda mais interessante quando nos acercamos de dois termos etimologicamente aparentados a Dichter e Dichtung: o verbo dichten e o adjetivo dicht. $\mathrm{O}$ verbo dichten tem dois significados principais, de acordo com o dicionário Pons. Quando em alemão se diz que “jd dichtet etw”, trata-se de uma literarisch erzeugen, ou seja, de uma produção literária, que se pode traduzir por "alguém compõe (ou escreve) algo"; trata-se, pois, do afazer poético. Mas dichten pode também significar estancar algo. De fato, o adjetivo dicht significa não somente vedado e impermeabilizado, como também espesso e denso. $\mathrm{E}$ aqui não é demais relembrar que das Dichte é, em Física, a densidade de um corpo qualquer. Dichtung, assim, parece ser uma operação de composição na qual as partes são arranjadas de modo a formar um todo denso e compacto; não à toa um dos processos psíquicos primários descritos com minúcia por Freud em 1900 se denomina Verdichtung, isto é, condensação. É como se a Dichtung, precedida pelo prefixo Ver-, fizesse parte desde sempre do funcionamento do inconsciente.

Se podemos de acordo com Laplanche e Pontalis (1985) caracterizar a fantasia como o enquadramento do desejo, a encenação do desejo num quadro narrativo específico, fica bem patente o caráter sintético da fantasia, caráter este presente também no afazer poético (e que o próprio verbo alemão dichten já traz consigo). Soria é precisa quanto a esse aspecto do fantasiar, ao afirmar que, a partir da análise de Freud das memórias encobridoras, "vemos que as palavras fantasia [Phantasie], fabricação [Fabrikation] e invenção ou composição [Dichtung] expressam um só ato: o de produzir [machen] uma representação a partir de condensação [Verdichtung] e deslocamento [Verschiebung] de diferentes desejos inconscientes" (Soria, 2010, p. 21).

Mas as relações entre fantasia e poesia não se limitam ao compartilhamento do caráter sintético. No artigo sobre romances familiares, Freud assevera que "é da natureza da neurose, e também de todo talento superior, uma atividade [imaginativa] frequente bastante peculiar" (Freud, 2015/1909a, p. 421). Em sua análise da Gradiva, Freud está a caracterizar Hanold (o personagem principal, cientista assíduo cujos sonhos e delírios ele virá a perquirir) e acerca dele enuncia: “mas, talvez com benévola intenção, a natureza lhe dera um antídoto e natureza totalmente não científica, uma fantasia extremamente vivaz, capaz de se impor não apenas nos sonhos mas, com frequência, também na vigília", completando em seguida: "tal dissociação entre a fantasia e o intelecto o destinava a ser um escritor (Dichter) ou um neurótico, ele contava entre aquelas pessoas cujo reino não é deste mundo" (Freud, 2015/1907, p. 25). Pouco antes, Freud afirmara que a fantasia do Dichter é aquilo que cria os seus personagens (idem, p. 16), e no artigo sobre o criador literário ele retoma o argumento, mostrando como o Dichter "constrói um mundo de fantasia que leva bastante a sério” (Freud, 2015/1908b, p. 327). A criação literária, assim, 
depende, para Freud, da atividade fantasística, sendo esta, com efeito, como que o substrato representacional daquela. E a partir desses trechos se pode entrever em que medida a temática da produção literária está, em Freud, muito próxima à da neurose. Mas por algum motivo o neurótico não é necessariamente poeta e viceversa, porém ambos têm algo em comum: uma prolixa atividade fantasiadora. Mais, ainda: a "dissociação" (ou autonomia) da fantasia prolífica como que destina um sujeito a ser ou poeta ou neurótico. Para dizer com Paul-Laurent Assoun (1980, p. 257), é "como se neurose e arte devessem ser decifradas como dois destinos de um mesmo processo".

Uma primeira nota sobre a Dichtung em Freud, portanto: sendo utilizada de forma quase indiscriminada para se referir a fantasias banais de seres não-poetas, ela parece fazer parte integrante de uma atividade basal do aparelho psíquico, o Phantasieren. Fantasiar é compor numa cena uma narrativa em que os desejos são satisfeitos, e é justamente a fantasia que é, para Freud, o substrato representacional necessário para a atividade do Dichter. Quando essas fantasias recebem um investimento excessivo e se segregam, ganhando como que uma autonomia dentro do aparelho psíquico, criam-se sintomas neuróticos. Mas uma fantasia prolífica é também a condição de possibilidade da criação literária - porém o poeta, por sua vez, não necessariamente é um neurótico. Deve existir algo, portanto, que diferencie a mera Dichtung presente nas fantasias em geral (que estão na origem dos sintomas neuróticos) das verdadeiras obras literárias. Na sua quinta conferência proferida nos Estados Unidos em 1909, Freud atribui a atividade artística a um enigmático dom artístico: "quando a pessoa desavinda com a realidade possui o dom artístico - que para nós é ainda um enigma psicológico -, pode converter suas fantasias em obras de arte, em vez de sintomas" (Freud, 2013/1910b, p. 279). Em que consiste, pois, esse "enigma psicológico" chamado dom artístico? Se Freud não consegue estabelecer aquilo que diferencia concretamente o Dichter do restante dos mortais, podemos ao menos buscar em sua obra os elementos que compõem o afazer poético e a criação de obras literárias.

Encontramos, parece-nos, uma pista em seu Mal-estar na cultura. Freud aí repete uma tese que já afirmara tantas outras vezes: a de que, com o estabelecimento do princípio de realidade, o homem mantém consigo uma forma de angariar prazer sem levar as intempéries da materialidade em conta, sendo esta forma precisamente a fantasia. Esta realiza desejos de forma imaginária: nem a realidade objetiva obstaculiza a realização imaginária do desejo, nem essa realização altera qualquer coisa da realidade. Diz, sobre isso, o trecho:

A satisfação é obtida de ilusões que a pessoa reconhece como tais, sem que a discrepância entre elas e a realidade the perturbe a fruição. 0 âmbito de que se originam tais ilusões é aquele da vida da fantasia; quando ocorreu o desenvolvimento 
do sentido da realidade, ele foi expressamente poupado do teste da realidade e ficou destinado à satisfação de desejos dificilmente concretizáveis. Entre essas satisfações pela fantasia se destaca a fruição de obras de arte, que por intermédio do artista se torna acessível também aos que não são eles mesmos criadores [Schöpferischen]. Quem é receptivo à influência da arte nunca a estima demasiadamente como fonte de prazer e consolo para a vida. Mas a suave narcose em que nos induz a arte não consegue produzir mais que um passageiro alheamento às durezas da vida, não sendo forte o bastante para fazer esquecer a miséria real (Freud, 2011, 1930, p. 25).

Eis a descrição algo dura feita então por Freud acerca da arte: esta produz apenas uma "suave narcose", que não tem muita serventia face à "miséria real". As obras de arte encontram-se entre as "ilusões" produzidas pelo fantasiar e aparentemente não são nada além disso. Mas o que diferencia a obra de arte das outras ilusões fantasísticas é que ela se torna acessível, por intermédio do artista, ao seu público, mesmo àqueles que não são criadores, e a palavra utilizada por Freud aqui é o adjetivo schöpferisch no plural e substantivado. Nesse trecho os homens se encontram divididos, por consequência, entre os criadores e os não-criadores. Dichter e schöpferisch parecem ser termos em íntima conexão, e o neurótico estaria entre os não-criadores. Seu sintoma é uma criação espontânea de seu psiquismo, que se faz à sua revelia. O Dichter, por outro lado, é um criador: ele cria obras de arte a partir das suas próprias fantasias. Vê-se em que medida a neurose surge no discurso freudiano quase como uma passividade frente às fantasias que habitam o inconsciente do sujeito, enquanto a criação literária inscreve-se numa atividade frente a essas mesmas fantasias. Isso já nos diz algo sobre a criação literária.

Mas voltemo-nos a esse termo alemão que fizemos ressaltar, o adjetivo schöpferisch. Segundo o Pons, ele significa criador ou, utilizado como advérbio, no domínio criativo. É derivado do substantivo Schöpfer, cujo primeiro significado é notório: quando precedido pelo artigo der, significa Deus, ou o Criador. Trata-se, pois, da Criação do Mundo, e o Schöpfer é precisamente o seu demiurgo primeiro. Gott, diz o dicionário, tal é o primeiro significado de Schöpfer. Mas ele pode significar também, para uma obra de arte (Kunstwerk), o seu criador, e para uma peça musical (Musikstück), o seu compositor. O termo se inscreve, pois, em duas regiões nas quais o ato criativo é fundante: a religiosa e a artística. O outro derivado de Schöpfer, o substantivo Schöpfung, reflete bem essa dualidade. Ele pode significar uma criação de um modo geral; se vier, no entanto, precedido do artigo die, encontra-se via de regra no domínio religioso e significa a Criação. Não à toa, die Schöpfungsgeschichte não é nada menos que o primeiro livro da Bíblia, o Gênesis, isto é, a história da Criação. Esse léxico, o que tem como base o radial Schöpf-, diz respeito a atos criativos, e parece aproximar o artista a Deus. 0 artista pode ser visto ao menos como aquele que, ao confeccionar sua obra de arte, esse novo objeto em que o fictício ganha presença enquanto realidade, cria um mundo, assim como Deus criou 
o Mundo. Ora, nós já vimos um trecho de Freud afirmar que o Dichter "constrói um mundo de fantasia”. Trata-se de seu artigo, publicado em 1908, intitulado Der Dichter und das Phantasieren. 0 título é já eloquente e toca precisamente no assunto que perquirimos: o escritor literário e o fantasiar. Dirijamo-nos a esse texto em sua versão original (Freud, 1972/1908c, pp. 213-223), ${ }^{2}$ a fim de caçar os trechos em que a criação está em jogo, e tentemos compreender, caso o termo se faça presente, como a Schöpfung é um processo constitutivo do ato criativo literário.

O parágrafo que abre esse pequeno artigo, de cerca de dez páginas, já nos parece sobremodo importante e nos dará muito material para reflexão. Suas duas primeiras palavras são "Uns Laien”, isto é, "a nós, leigos”, conjunto este que será contraposto muito precisamente ao Dichter. Ou seja, aqueles que em 1930 serão chamados de "não-criadores" (negação do adjetivo substantivado schöpferisch), em 1908 são ditos muito simplesmente "leigos" (coletivo no qual Freud põe a si mesmo, não o esqueçamos). Em que está implicado esse coletivo, "nós, os leigos"? Numa espécie de interesse: "a nós, os leigos, sempre interessou saber de onde essa peculiar personalidade, o Dichter, pega seus materiais". É como se nós, os nãopoetas, sofrêssemos dessa enervante curiosidade sempiterna: como é que esses seres, tão similares a nós, conseguem nos tocar de tal modo com suas criações? O texto continua: sempre nos interessou saber "como ele consegue capturar-nos com eles [esses materiais] e provocar em nós excitações das quais nós nem sequer nos acreditávamos capazes". Mas questionar o Dichter acerca de seu ofício será em vão, pois ele mesmo, quando interrogado, não dará informação satisfatória sobre o assunto, coisa que só aumenta o nosso interesse. E Freud termina o parágrafo de abertura com afirmações fundamentais: "a melhor compreensão sobre as condições da escolha do material poético e sobre a essência da arte do arranjo poético [poetischen Gestaltungskunst] não contribuirá em nada para transformar a nós mesmos em poetas" (Freud, 1972/1908c, p. 213).

Não se trata, portanto, de um saber consciente, baseado em conceitos ou em intelecções científicas, mas sim de um saber fazer. 0 escritor escreve, ele age, mesmo sem estar ciente da essência mesma desse seu agir e da técnica que constitui o seu ofício. E essa é uma técnica específica (que consiste não só na escolha do material a ser trabalhado, como num arranjo formal aparentemente refinado) a que poucas pessoas têm acesso. São essas pessoas que merecem o epíteto de Dichter.

Após essas palavras preciosas e respeitosas sobre o Dichter, a frase inicial do parágrafo seguinte expressa em grande parte o caráter do artigo: "se ao menos pudéssemos encontrar em nós ou em nossos pares uma atividade [Tätigkeit] de certa

2 Utilizaremos a versão contida na edição das Gesammelte Werke, em seu Band VII (Werke aus Jahren 1906-1909), pp. 213-23. Como apoio para as traduções dos trechos em alemão, usaremos a tradução brasileira por nós já citada, da edição da Companhia das Letras. 
forma aparentada ao poetizar [Dichten]!” (idem, ibidem). Exclamação retórica, pois que Freud encontrará, como veremos, outras Tätigkeiten similares ao Dichten: o jogo infantil e o fantasiar. E nisso consistirá, em grande parte, o percurso do texto freudiano: aproximar, pela via das atividades "ordinárias" da alma afins ao afazer poético, os dois grupos de pessoas apresentados logo no seu início - nós, os leigos, vulgares e não-criativos, e os poetas, essas pessoas tão peculiares. Nosso objetivo, por outro lado, é acercar-nos de onde essa aproximação tipicamente freudiana deixará lacunas pelo caminho, ou seja, é tratar de encontrar os pontos de diferença e distância entre as criações literárias e as atividades anímicas que thes são aparentadas. A própria letra freudiana nos dará o ensejo para tanto.

A primeira movimentação da estratégia freudiana será invocar as brincadeiras das crianças. Surge assim mais uma questão retórica: "não deveríamos buscar já na criança os primeiros traços da atividade [Betätigung] poética?" (idem, p. 214). A resposta à pergunta encontra-se já nela mesma: é na atividade da criança que Freud irá descrever algo não só similar ao "criar do poeta" (das Schaffen des Dichters, expressão empregada logo antes), mas que também compartilha dos mesmos mecanismos. "Talvez nós devêssemos dizer: cada criança que brinca comporta-se como um Dichter, ao criar [erschaffen] para si mesmo um mundo próprio ou, melhor dizendo, ao transferir as coisas de seu mundo para uma nova ordem que the agrade" (idem, ibidem). Notemos que o ato de criar um mundo próprio é atribuído tanto à criança que brinca quanto ao escritor que poetiza. 0 próximo passo de Freud é explicar as relações, implícitas no ato mesmo de criar, entre o novo mundo, o criado, e o mundo "antigo", que, presumimos, a criança não pôde criar.

Essas relações são muito precisamente as de negação e apoio. Donde a célebre sentença freudiana: "o oposto do jogo não é a seriedade, mas sim - a realidade [Wirklichkeit]" (idem, ibidem). E a atitude de Freud perante o jogo infantil será análoga à atitude da criança mesma que brinca: esse mundo próprio que a criança cria para si mesma deve ser levado a sério. Pois bem, a realidade é o oposto do jogo, mas é também a base a partir da qual se erige o novo mundo da brincadeira: "a criança diferencia muito bem seu mundo do jogo [Spielwelt], apesar de todo o seu investimento de afeto, da realidade [Wirklichkeit] e com prazer apoia [anlehnt] seus objetos e relações imaginários nas coisas concretas e visíveis do mundo real [der wirklichen Welt]" (idem, ibidem). A Wirklichkeit, ou o mundo real (die wirkliche Welt), é, pois, a um só tempo o oposto (Gegensatz) e o suporte ou apoio material (Anlehnung) do mundo criado pela criança. Ocorre que a criança necessita de objetos concretos para realizar seu jogo, e eis a diferença substancial entre o brincar infantil e o fantasiar adulto: este não requer objetos concretos, basta-lhe aprazer-se no nível representacional. Assim, "nada além desse apoio [Anlehnung] diferencia o 'brincar' da criança do 'fantasiar'” (idem, ibidem). 
Aparentemente, anuncia-nos Freud, o adulto para de brincar. Ele cresce, e a brincadeira infantil permanece no passado. Mas isso não é inteiramente correto. “Assim também o adulto, quando cessa de jogar, não faz nada além de resignar ao apoio em objetos reais; em vez de jogar, ele agora fantasia. Ele constrói [baut] para si castelos de ar, ele cria [schafft] aquilo que se denomina sonhos diurnos" (idem, p. 215). Notemos que Freud em seu texto dispõe, como um verdadeiro casal, os verbos jogar e fantasiar: „anstatt zu spielen, phantasiert er jetzt“. Refinadíssimo jogo de linguagem: o segundo ato, o Phantasieren, é uma continuação do primeiro, o Spielen, e é na disposição de uma sequência, separados por uma vírgula, que marca o tempo do texto e o tempo do crescimento do adulto, que eles são apresentados ao leitor.

As crianças constroem castelos de areia; os adultos, castelos de ar. A diferença entre as duas criações está na falta de necessidade, para o adulto, de apoio em objetos reais, palpáveis. E, diferentemente do jogo infantil, que pode ser feito às vistas de todos, o fantasiar adulto é quase sempre feito secretamente e assim mantido. "O adulto, porém, envergonha-se das suas fantasias e as esconde dos outros, ele as cultiva como as suas intimidades mais pessoais, e via de regra ele preferiria confessar seus crimes a comunicar suas fantasias" (idem, ibidem). Eis, no entanto, algo que caracteriza tanto o brincar infantil quanto o fantasiar adulto: ambas as atividades não são feitas visando a um público receptor. A criança brinca talvez à vista dos adultos, mas essa vista não tem importância para a sua atividade: encerrada em seu próprio mundo, a criança se regozija numa espécie de narcisismo a céu aberto. Os adultos, por sua vez, tiveram de abandonar essa atividade pueril que é o jogo, mas a mantiveram eu seu íntimo, sob a forma da fantasia; esta, porém, é mantida oculta, longe da vista dos outros.

Nessa sequência lógica e cronológica do Spielen e do Phantasieren, um terceiro termo será então inserido: nada menos que o Dichten. À penúltima página do texto, Freud anuncia que "a poesia [Dichtung] é, como o sonho diurno, uma continuação e um substituto do antigo brincar infantil” (idem, p. 222). Por que a montagem dessa série tripartite? Isso já fora esclarecido, algumas páginas antes. "O Dichter faz, então, o mesmo que a criança que joga; ele cria um mundo de fantasia [erschafft eine Phantasiewelt] que ele toma muito a sério, quer dizer, ele o dota de grandes quantias de afeto, enquanto o diferencia pronunciadamente da realidade [Wirklichkeit]" (idem, p. 214). O texto continua:

e a língua registrou esse parentesco entre jogo infantil [Kinderspiel] e criar poético [poetischem Schaffen], ao chamar de jogos [Spiele] aqueles espetáculos do Dichter que requerem o apoio em objetos concretos e que são aptas à apresentação: comédia [Lustspiel] e tragédia [Trauerspiel]; e chamando de ator [Schauspieler] a pessoa que as representa (idem, ibidem). 
A língua alemã, quão sábia, mantém em seu léxico a vinculação umbilical entre o brincar infantil e a criação do Dichter: este, por fim, é também spielende, ele também cria um mundo de fantasia. Mas esse parentesco não esconde a grande diferença entre as duas atividades tão símiles: o Spiel do Dichter, como o próprio trecho traz já implícito, é endereçado a um público, pois ele engendra apresentações. E eis-nos de volta à questão presente no parágrafo de abertura - a obra do artista só atinge o seu sucesso perante seu público justamente por não ser real. Tal o que diz Freud a esse respeito:

\begin{abstract}
da irrealidade do mundo poético [Unwirklichkeit der dichterischen Welt] resultam, no entanto, consequências muito importantes para a técnica artística [die künstlerische Technik], pois muito que não poderia ocasionar gozo, sendo real, pode-o, porém, no jogo da fantasia [Im Spiele der Phantasie], e muitas excitações que em si mesmas são propriamente penosas podem tornar-se fonte de prazer para os ouvintes e espectadores do Dichter (idem, ibidem).
\end{abstract}

Ora, a questão da técnica artística reaparece, e, embora faça derivar o sucesso do mundo poético da sua própria irrealidade, Freud não responde à questão basal: com que mecanismos o artista causa prazer a partir de materiais que, em si mesmos, são penosos? Nós voltaremos a essa questão, pois ela mesma retornará, ao fim do texto.

Antes disso, no entanto, deixemos notado algo que nos parece fundamental a respeito desse texto. Como as citações que pusemos em relevo o mostram, pululam no artigo expressões referentes ao ato de criar. São muitos os verbos e substantivos relativos a esse tema empregados por Freud. Todo o artigo trata, com efeito, de criações dos mais diversos tipos. Na bela descrição da relação da fantasia com as três dimensões cronológicas do tempo, Freud diz que o trabalho anímico, premido por uma situação atual que desperta certos desejos do sujeito, cria (schafft) uma fantasia ou um sonho diurno, tendo como modelo uma situação do passado em que tais desejos foram satisfeitos, e o faz numa cena imaginária no futuro. "Desse modo, passado, presente e futuro são justapostos como se num fio pelo desejo que o percorre" (idem, p. 217). Uma página adiante, é precisamente "a superabundância e superpotência da fantasia que cria (stellt... her) as condições para a queda numa neurose ou numa psicose" (idem, p. 218). É fato: Freud criou um texto para falar de criações. O brincar infantil, o fantasiar adulto, o trabalho anímico, a confecção de uma obra literária, a queda numa neurose. Para bem ou para mal, tudo é criação nesse pequeno texto. É notável aí a alta proliferação (a superabundância, dir-se-ia) do léxico relativo à criação: schaffen, erschaffen, bauen, herstellen, bilden. Um termo, no entanto, ainda se encontra faltante: justamente o que procurávamos, Schöpfung. Mas ele é o que mais é utilizado por Freud, aparecendo exatas nove vezes.

A primeira delas, na página 215 . E, para nossa surpresa, não há nada de 
especial no uso dessa palavra cara ao mundo eclesiástico. Quando dizia sobre o homem envergonhado pelas suas intimidades fantasiosas, Freud complementa que "pode ocorrer que ele se considere o único que forma [bildet] tais fantasias e não suspeite da propagação geral de criações [Schöpfungen] muito similares em outras pessoas" (idem, p. 215). Assim, fantasias as mais banais são já um tipo de Schöpfung, não havendo nada de especial, portanto, no uso desse substantivo. Quatro páginas adiante, ele novamente é usado para se referir a fantasias quaisquer: "a língua, na sua sabedoria insuperável, há muito dirimiu a questão sobre a essência dos sonhos, ao deixar que as criações arejadas [die luftigen Schöpfungen] daquele que fantasia também se chamem 'sonhos diurnos'” (idem, p. 219). À mesma página, entretanto, surge a primeira utilização da palavra para se referir às criações poéticas. O Dichter é mencionado, e suas obras são ditas seine Schöpfungen (idem, ibidem). ${ }^{3} \mathrm{E}$ o termo marca presença poucas linhas depois, quase insistentemente, mas dessa vez a respeito das obras de autores não muito ambiciosos, que não são considerados pela crítica como os mais excelsos (ao contrário, têm sua obra amplamente difundida e conquistaram leitores fiéis). As palavras escolhidas por Freud revelam uma vez mais que uma Schöpfung, mesmo os escritores menos importantes são capazes de fazê-la, pois aqui ele não os denomina Dichter, mas sim Erzähler, isto é, narradores (idem, ibidem). Ora, tanta importância havíamos dado ao Schöpfer e à sua Schöpfung, para que Freud dissesse serem Schöpfungen as narrativas mais vulgares e as fantasias mais banais! E, perto do fim do texto, Freud fala ainda de criações que não são livres (nicht freie Schöpfungen), histórias feitas a partir de um material já concebido e amplamente conhecido - isto é, é bem possível que o ato de criar não seja tão criativo assim. Mas é nossa vez, agora, de colocar uma questão retórica: haveria, porém, algo que pudesse diferenciar as criações dos Dichter das outras?

Esse algo, no texto, é um adjetivo. Ou melhor, dois adjetivos, que são praticamente sinônimos. Assim como faz derivar o fantasiar adulto do jogar infantil, Freud remonta a criação literária à criação de fantasias. O texto é peremptório, e diz que as narrativas literárias têm a mesma estrutura que as dos sonhos diurnos, cuja confecção pelos não-poetas é praticamente espontânea. Ele admite, todavia, a existência de obras cuja trama muito difere do tecido monótono dos sonhos diurnos. Mesmo assim, essa diferença é apenas aparente:

nós de modo algum ignoramos que muitíssimas criações poéticas [dichterische Schöpfungen] se mantêm bastante afastadas do modelo do sonho diurno ingênuo, mas eu não posso conter a suposição de que mesmo os desvios mais extremos poderiam ser correlacionados com esse modelo através de uma série ininterrupta de transições (idem, p. 220).

30 mesmo uso do termo (ou seja, relativo ao Dichter e precedido pelo pronome seine) aparece à página 221. 
A atenção deve recair no adjetivo dichterisch, que denota uma especificidade das Schöpfungen em questão. E vemos, à página seguinte, uma nova aparição do termo, precedido agora por um outro adjetivo (quase sinônimo). Equiparar o poeta com aquele que fantasia é equiparar a criação poética [poetischen Schöpfung] com o sonho diurno (idem, p. 221); percebe-se como, nessa comparação entre duas "personalidades", o importante não é o seu caráter ou o seu temperamento, mas sim duas atividades bastante específicas. 0 que está em jogo para Freud, ao menos nesse texto, são diferentes modalidades, comparáveis entre si, de agir. Tudo indica, portanto, que, malgrado seu pertencimento ao conjunto maior de Schöpfungen quaisquer, as obras literárias têm caracteres especiais, merecendo ser chamadas de dichterische (ou poetische) Schöpfungen. Essa concomitante familiaridade e estranheza entre as modalidades de criar e de criação constitui precisamente o ponto de tensão do texto.

E o modo com que Freud o termina é prova disso. Na sua penúltima página, Freud admite: pois bem, fizemos derivar a criação poética de uma criação anterior, espontânea, da criança, o brincar, cujo substituto na vida adulta é a criação de sonhos diurnos. Mas quanto ao efeito da arte pouco se falou: "o outro problema com quais meios o poeta produz [erziele] em nós efeitos de afetos, que ele provoca [hervorruft] através da suas criações [seine Schöpfungen] - nós sequer o tocamos ainda" (idem, ibidem). Ora, esse outro problema é justamente $o$ problema, $a$ questão que escapa desse texto, quase como um resíduo de toda a reflexão que Freud pôde perfazer.

Tanto é que é com ela que de fato é finalizado esse seu pequeno e belo artigo. Em suas considerações finais, Freud retoma aquilo que antes já dissera: que os homens escondem, por vergonha, as suas fantasias. E acrescenta:

nós seríamos repugnados por essas fantasias, se viéssemos a saber delas, ou no máximo permaneceríamos frios perante elas. Quando, porém, o poeta representa para nós as suas peças [seine Spiele] ou nos narra aquilo que nós somos inclinados a elucidar como sendo os seus sonhos diurnos pessoais, nós sentimos um grande prazer, que provavelmente confluem de várias fontes (idem, p. 223).

Em vez de repulsa ou frieza, eis que nos sobrevém um prazer dos maiores - a questão toda se centra nisso. "Como [Wie] o poeta consegue fazer isso, eis o seu próprio segredo; na técnica [Technik] de superar aquela repulsa, que certamente tem a ver com as barreiras que se erguem entre cada eu isolado e os outros, consiste a verdadeira ars poetica" (idem, ibidem).

Esse Wie (como) é o grande problema, é o segredo que o mágico nunca revela ao seu público. 0 problema, Freud nos indicou no início do texto, é que nesse caso o próprio autor da mágica não poderia revelar-nos o segredo de sua criação. Nesse Wie, nessa técnica específica reside toda a questão da criação poética. Isso porque, tendo-a derivado de outras criações, universalmente existentes entre os homens (o 
brincar infantil e o fantasiar do adulto), Freud não fez mais do que encontrar suas origens. Fazendo-o, não acaba por desvelar o segredo da eficácia da arte: com que mecanismos o Dichter consegue superar a repulsa que sentimos pelas fantasias alheias e, não só isso, angariar prazer a nós mesmos, um prazer de que nem sabíamos ser capazes. E o Dichter faz isso a partir de suas próprias fantasias, ou seja, o material dessa conquista é um conjunto de histórias fictícias que em nada nos agradariam caso fossem relatadas tais quais foram concebidas originalmente. A ars poetica sobra, ao fim desse texto, como o grande enigma que o maquinário conceitual freudiano não consegue capturar.

Deixemos notado que em seus últimos parágrafos Freud afirma, de passagem, que a eficácia das obras literárias está no chamado pré-prazer que o Dichter logra nos causar: com um arranjo formal em que os sonhos diurnos encontram-se por assim dizer amenizados, a obra nos vai emocionando, dando-nos prazeres prévios até nos permitir, quiçá em seu clímax, grandes liberações de tensões pulsionais. Essa hipótese freudiana, embora valiosa, não nos parece, entretanto, suficiente para explicar a eficácia da obra de arte - problemática esta em que se inscreve também o conceito de sublimação, espinhoso por si só, e que mereceria um estudo à parte. Isso ainda parece nos apontar que os efeitos estéticos de uma obra de arte não são investigados por Freud através de uma mera análise do seu conteúdo, mas sim a partir de um processo criativo (o sublimatório, por exemplo), com o qual o que é fantasmático em um (o Dichter) toca, sub-repticiamente, no que é fantasmático no outro (o leitor ou espectador). Donde a importância do léxico relativo à criação que fizemos destacar. Mas as coisas não são tão simples, pois a própria fantasia, coisa comum, é já uma criação, como o próprio texto nos informa.

No texto, o termo Schöpfung, que pensáramos poder diferenciar o Dichter do homem não-criativo, é usado também para fazer referência a fantasias e sonhos diurnos no geral. Ou seja, diz respeito a criações fictícias banais, correntes, das quais todo ser humano é capaz. Quando se refere à criação literária, por outro lado, ele vem acompanhado de dichterisch ou de poetisch. A questão toda reside, portanto, na passagem das meras Schöpfungen para as dichterische Schöpfungen. Se fizéssemos o mesmo com Dichtung, que, como vimos, Freud emprega indiscriminadamente para poesias e composições imaginárias banais, acabaríamos com os termos poetische Dichtung ou mesmo dichterische Dichtung - este último, uma redundância que mostra a encruzilhada em que nos encontramos. Porém aqui há mais que redundância: está-se frente a uma possível tautologia; tal é, de fato, o risco do empreendimento tipicamente freudiano de aproximar, genética e formalmente, formações psíquicas tão díspares em aparência como são o jogo infantil, a fantasia adulta e a criação literária: o de explicar a poesia, por fim, pela poesia mesma. Mas conquanto se possa chegar a essa conclusão, em se levando o esquema lexical freudiano às suas 
últimas consequências, deve-se dizer, entretanto, que o próprio esquema conceitual freudiano deixa entreabertas algumas veredas através das quais novos e renovados fios lógicos podem ser apreendidos. A criação de uma cena sintética em que o desejo é realizado é algo banal, espontâneo do ser humano desde a sua infância. A diferença entre a mera Dichtung e uma dichterische Schöpfung está no Wie, na Technik que supera nossa aversão aos conteúdos de nossas próprias fantasias.

Parece-nos, e o diremos a título de indicação, que a dichterische Schöpfung tem mais uma grande diferença com relação às Schöpfungen banais. Estas nos deixam frios ou nos causam aversão quando apresentadas tais quais são; elas requerem uma análise para que possam ser-nos interessantes, para que possam revelar-nos algo a respeito do aparelho psíquico, por exemplo. Elas só nos interessam enquanto objetos do saber. As dichterische Schöpfungen, ao contrário, apesar de serem passíveis de análise (e a obra de Freud está lotada desse tipo de destrinça), fazem parte do próprio arsenal analítico da psicanálise. Elas são verdadeiros ajudantes do afazer teórico de Freud (assim como a criança, em seu Schöpfen, se apoia no mundo material para brincar, Freud se apoia nos escritores para teorizar). "É assim a poesia que se põe em Freud a serviço da teoria, a Phantasie a serviço da Wissenschaft" (Altounian, 2003, p. 81). A história de Édipo não requer muito simplesmente uma análise para que componha uma faceta fundamental da teoria freudiana - ela mesma faz parte da teoria, e o que Freud faz é, em diversos momentos de sua letra, repeti-la sem seus contornos dramatúrgicos originários. E essa história só pôde ter sua importância na medida em que foi alçada ao estatuto de mito e, talvez mais que isso, na medida em que foi elaborada numa criação literária, o Édipo rei de um dos mestres do teatro grego antigo (Green, 1992, p.87). Essas poetische Schöpfungen são, pois, muito mais do que meras histórias fictícias. Elas mesmas são constituintes da própria teoria. Elas são veros sujeitos do saber, se pensarmos por esse lado. Em uma palavra: nós analisamos as meras Dichtungen; as dichterische Schöpfungen, por sua vez, nos analisam.

Para finalizar, retomemos ainda um último local específico em que o vocábulo Schöpfung aparece sob a pena freudiana. N'O futuro de uma ilusão, Freud afirma: "não se pode negar que ela [a psicanálise] é criação [Schöpfung] minha" (Freud, 2014/1927, p. 275). Não se pode ignorar, assim, que Freud é também schöpferisch - sua criação, no entanto, não é dichterisch, mas sim teórica. Talvez haja mais em comum entre o criar poético e o teorizar freudiano do que se pode suspeitar a princípio. Não que a psicanálise produza obras de arte, mas que, em seu trabalho a um só tempo teórico, investigativo e terapêutico, ela é capaz de gerar, a partir e através das fantasias mais repugnantes de cada um, um crescimento anímico de que nós sequer desconfiávamos ser capazes. Nesse Wie, nessa Technik que elabora os conteúdos fantasísticos que nos causam uma imensa repulsa consiste o verdadeiro 
método freudiano. É possível que se encontre aí "a intimidade profunda entre os discursos psicanalíticos e poéticos" (Pagès, 2010, p. 17), para usar a expressão de Pagès. Se o poeta nos emociona ao elaborar o universal fantasmático que nos habita, e se a metapsicologia, a verdadeira Schöpfung freudiana, é a elaboração teórica, num edifício conceitual, das fantasias dos sujeitos que sofrem no divã, talvez aí resida o parentesco entre o criar poético e o analítico.

\section{Referências}

Altounian, J. (2003). L'écriture de Freud. Paris: Presses Universitaires de France. Assoun, P.-L. (1980). Freud et Nietzsche. Paris : Presses Universitaires de France.

Bayard, P. (2004). Peut-on appliquer la littérature à la psychanalyse ?. Paris : Les Éditions de Minuit.

Freud, S. (1972/1908c). „Der Dichter und das Phantasieren“. In: Gesammelte Werke, Band VII (Werke aus Jahren 1906-1909), pp. 213-23. Frankfurt am Main: Fischer Verlag.

Freud, S. (1989/1899). "Sobre los recuerdos encubridores". Tradução de José L. Etcheverry. In: Obras Completas, vol. 3, pp. 297-305. $2^{\text {a }}$ ed. Buenos Aires: Amorrortu editores.

Freud, S. (2010/1918[1914]). "História de uma neurose infantil ("O homem dos lobos”)". Tradução de Paulo César de Souza. In: Obras Completas, vol. 14, pp. 13-160. $1^{\text {a }}$ ed. São Paulo: Companhia das Letras.

Freud, S. (2011/1930). O mal-estar na civilização. Tradução de Paulo César de Souza. São Paulo: Penguin Classics Companhia das Letras.

Freud, S. (2013/1909c). "Observações sobre um caso de neurose obsessiva ("O homem dos ratos”)". Tradução de Paulo César de Souza. In: Obras Completas, vol. 9, pp. 13-112. $1^{\text {a }}$ ed. São Paulo: Companhia das Letras.

Freud, S. (2013/1910a). "Um tipo especial de escolha de objeto feita pelo homem (Contribuições à psicologia do amor I)". Tradução de Paulo César de Souza. In: Obras Completas, vol. 9, pp. 334-346. $1^{a}$ ed. São Paulo: Companhia das Letras.

Freud, S. (2013/1910b). "Cinco lições de psicanálise”. Tradução de Paulo César de Souza. In: Obras Completas, vol. 9, pp. 7-51. $1^{\text {a }}$ ed. São Paulo: Companhia das Letras.

Freud, S. (2014/1927). “O futuro de uma ilusão”. Tradução de Paulo César de Souza. In: Obras Completas, vol. 17, pp. 231-301. $1^{\text {a }}$ ed. São Paulo: Companhia das Letras.

Freud, S. (2015/1907). "O delírio e os sonhos na Gradiva de W. Jensen". Tradução de Paulo César de Souza. In: Obras Completas, vol. 8, pp. 13-122. $1^{\text {a }}$ ed. São Paulo: Companhia das Letras.

Freud, S. (2015/1908a). "As fantasias histéricas e sua relação com a bissexualidade". Tradução de Paulo César de Souza. In: Obras Completas, vol. 8, pp. 339-349. $1^{\text {a }}$ ed. São Paulo: Companhia das Letras.

Freud, S. (2015/1908b). "O escritor e a fantasia”. Tradução de Paulo César de Souza. 
In: Obras Completas, vol. 8, pp. 325-338. $1^{\text {a }}$ ed. São Paulo: Companhia das Letras. Freud, S. (2015/1909a). “O romance familiar dos neuróticos”. Tradução de Paulo César de Souza. In: Obras Completas, vol. 8, pp. 419-424. $1^{\text {a }}$ ed. São Paulo: Companhia das Letras.

Freud, S. (2015/1909b). "Análise da fobia de um garoto de cinco anos ("O pequeno Hans")". Tradução de Paulo César de Souza. In: Obras Completas, vol. 8, pp. 220286. $1^{\text {a }}$ ed. São Paulo: Companhia das Letras.

Gómez Mango, E. (2012). “Nota sobre o Dichter”. In: Pontalis, J.-B. \& Gómez Mango, E. Freud com os escritores, pp. 12-18.

Green, A. (1992). OEdipe, Freud et nous, in La déliaison. Paris : Les belles lettres, pp. 69-146. Trabalho original publicado em 1981.

Laplanche, J. \& Pontalis, J. B. (1985). Fantasme originaire, Fantasme des origines, Origines du fantasme. Paris : Editions Hachette, Trabalho original publicado em 1964.

Pagès, C. (2010). « Nach des Dichters Worten ». Freud et la référence poétique. L'enje lacanien, 1 (14), pp. 13-34.

Soria, A. A. S. (2010). Interpretação, sentido e jogo: um estudo sobre a concepção de fantasia (Phantasie) em Sigmund Freud. (Tese de doutorado, Faculdade de Filosofia, Letras e Ciências Humanas, Departamento de Filosofia, Universidade de São Paulo, São Paulo, SP).

Recebido em: 09.03.2020

Aceito em: 25.06.2020

Esta obra está licenciada com uma Licença Creative Commons Atribuição-NãoComercial-Compartilhalgual 4.0 Internacional.

https://creativecommons.org/licenses/by-nc-sa/4.0/

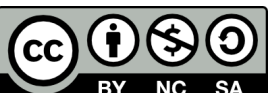

